University of California, Hastings College of the Law UC Hastings Scholarship Repository

Faculty Scholarship

$1-1-1996$

\title{
The International Organization for Standardization and the Drafting of Private Environmental Standards
}

Naomi Roht-Arriaza

UC Hastings College of the Law, rohtarri@uchastings.edu

Follow this and additional works at: https://repository.uchastings.edu/faculty_scholarship

\section{Recommended Citation}

Naomi Roht-Arriaza, The International Organization for Standardization and the Drafting of Private Environmental Standards Am. Soc'y Int'l L. Proc. 90 (1996).

Available at: https://repository.uchastings.edu/faculty_scholarship/1299 


\section{HEINONLINE}

Citation: 90 Am. Soc'y Int'I L. Proc. 1781996

Provided by:

UC Hastings College of the Law

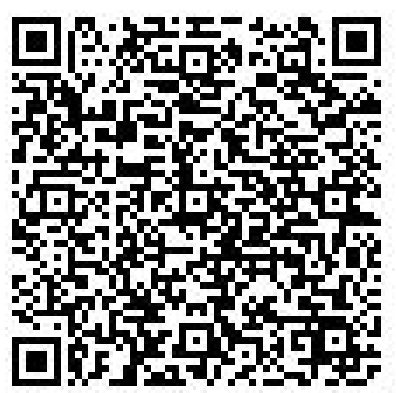

Content downloaded/printed from HeinOnline (http://heinonline.org)

Thu Jun 16 13:34:56 2016

-- Your use of this HeinOnline PDF indicates your acceptance of HeinOnline's Terms and Conditions of the license agreement available at http://heinonline.org/HOL/License

-- The search text of this PDF is generated from uncorrected OCR text.

-- To obtain permission to use this article beyond the scope of your HeinOnline license, please use:

https://www.copyright.com/ccc/basicSearch.do?

\&operation $=$ go\&search Type $=0$

\&lastSearch $=$ simple\&all=on\&titleOrStdNo=0272-5037 


\title{
Transparency, Accountabmity and Private Actors
}

The panel was convened at 10:45 a.m., on Thursday, March 28, by its Chair, Lee A. Kimball,* who introduced the panelists: Naomi Roht-Arriaza, Associate Professor at the University of California, Hastings College of Law; Clifton Curtis, Political Advisor, Greenpeace International; and Patrick O. Gudridge, Professor at University of Miami School of Law.

\section{The International Organization for Standardization and the Drafting of Private Environmental Standards}

\author{
By Naomi Roht-Arriaza**
}

I will address the question whether, and how, standards development by private actors responds to concerns about the lack of transparency in public law negotiations and accountability in the enforcement of public international law, in particular, environmental law. I would like to tackle those questions by looking at the process of developing global environmental management standards (EMS), and auditing, labeling and life-cycle assessment standards in the International Organization for Standardization (ISO). ${ }^{1}$ I will first briefly describe the standards and their origins, and then turn to the process by which they were drafted and compare that process with the public law-making process. I will then consider the interrelationship between the drafting process and the way in which compliance is envisioned by raising some questions about accountability and private actors.

\section{Some Definitions}

The environmental management standard, which I will focus on as it is the furthest along and is the centerpiece, provides for organizations to set up procedures to ensure that they are aware of the environmental effects of their activities and continually improve their processes for minimizing these effects, including feedback procedures and audits of the system. The existence of an adequate system may be self-certified or may be subject to outside verification in order to certify that an organization is meeting the standard.

ISO is a federation of over 100 standardization bodies, one from each country. Each national delegation determines its own composition, which is supposed to represent a balance of producer, consumer, small business and other relevant interests. While many governments participate through their standards institutes, governments are only one actor among many within the national delegations, and have no pride of place.

In the late 1980s, ISO pioneered a global standard for quality control, the ISO 9000 series, which quickly became required in practice for many companies selling in global markets because their customers preferred ISO-certified firms. This was one source of the model for development of environmental management standards. Other factors leading up to development of these standards were the proliferation of eco-labeling programs in different countries, as well as of private corporate codes of conduct on the environment (such as that of the Business Council for Sustainable Development or the CERES Principles), which raised problems of multiple registrations and requirements for companies operating in global markets. Most important was the adoption at the European Commu-

\footnotetext{
* Independent Consultant, Treaty Development and International Institutions.

** University of California, Hastings College of Law.

${ }^{1}$ A more detailed treatment of the development of the ISO 14000 series standards and their implications appears at 22 EcoL. L. Q. 549 (1995). An updated and expanded article considering many of the same issues will appear in the 1995 YEARBOOK OF INTERNATIONAL ENVIRONMENTAL LAW.
} 
nity-level of a regulation setting up an Eco-Management and Auditing Scheme ${ }^{2}$ (EMAS) whereby industrial sites could voluntarily put in place policies, plans and systems to analyze the effects of their activities on the environment, make public a certain amount of information on those effects, and continuously improve their performance in minimizing these effects, all to be verified by an outside evaluator. They could then call themselves certified under the scheme. Companies based outside Europe began worrying that such a scheme might provide an unfair advantage to European producers in European markets, and so they pushed for a globally applicable standard on environmental management and auditing.

That is a thumbnail background sketch of the origins of the ISO 14000 series standards. Let me turn now to the process of creating the standards, and some of the questions it raises about transparency. As I said, the process was not dominated by governments, although government officials were a more or less prominent part of many national delegations. Theoretically, therefore, it should have been possible to ensure greater transparency, as the meetings were open and anyone could participate. Theoretically also, a model like ISO-where all interested parties could be at the table and negotiate the content of standards-could result in a more democratic process of lawmaking on an international level, answering some of the criticisms of the public international law process as undemocratic, ${ }^{3}$ and responding to the need to include NGOs as well as producers on a level playing field.

In practice, large transnational corporate interests dominated the discussions. To be specific, heads of the environmental compliance/health and safety shops of major U.S. and European corporations, especially chemical, pharmaceutical and energy companies, and their lawyers, played key roles in the initial shaping and drafting of the standards. Although in theory the national delegations are open and are supposed to seek "balance," in practice there was very little representation of small and medium businesses, of consumer groups, or of most environmental NGOs. On a global level the main players, at least initially, were the United States, Canada and the Western European countries; only last year, when the draft standard was almost complete, did a significant number of developing countries participate in the meetings where the final draft was hammered out.

Why did this marked difference exist between the stated goal of "balance" and the reality of Northern corporate domination? Money, for one thing. As part of a private voluntary organization, each member of the delegation pays for his or her own travel, and meetings are held-several per year-all over the world. Only corporate representatives tend to have the money to go to all of them, providing the core of "regulars" who end up doing most of the drafting. Diffuse versus concentrated interests also explains part of the problem; the corporate entities seeking alternatives to "command-and-control" regulation had a much greater ability to focus on the exact language of the standards than NGOs, who were fighting on many fronts simultaneously. Moreover, since the process was private, there was no need to publicize the meetings, nor the intent or emerging shape of the standards. The documents of the meetings were difficult for outsiders to get and were often too technical or full of allusions to informal discussions to be of much help. The ISO had never before been a site of contested public policy making so its procedures were mystifying; as a result, the full implications of the process were lost on both NGOs and on many less-developed countries (LDCs) until rather late in the game. Although participants lament the lack of adequate early NGO input, those outside the corporate

\footnotetext{
${ }^{2}$ Council Regulation 1836/93. The regulation became effective as of April 1995.

${ }^{3}$ The lack of democratic input into international law decision making has been an issue in the ratification of the North American Free Trade Agreement and the Maastricht Treaty.
} 
community-and developing country representatives-complained about being marginalized and excluded. Finally, last year, a travel grant allowed for greater LDC participation and some NGOs began attending, but by that time their role was mostly one of damage control because the basic outlines were set. The question remains whether some other set of procedures-such as earlier travel grants and better publicity-could have remedied the problems, or whether this "interest group" model of decision making will always favor more powerful and monied interests over others.

One key question in drafting was the possibility that the resulting standards could benefit large, developed-country industries (which would find it relatively easy to comply) and prejudice small and developing country industries. Those of you who have followed the trade and environment issue will recognize this problem, which has been central to the public debate over harmonization and minimum global environmental standards. The ISO 14000 EMS standards ended up adopting the position of the U.S. delegation, which argued that only a purely procedural standard that imposes no substantive obligations to improve the environment but merely requires companies to put in place management systems, would avoid possible prejudice to small or developing country industry. Therefore, the 14001 standard contains no substantive requirements beyond a commitment to continual improvement of the management system, a commitment to comply with local law, and a commitment to pollution prevention-with a definition of "prevention" so broad as to be meaningless.

European demands for third party auditing and public disclosure of actual improvements to the environment and for the use of the best available technology, rather than just improvements to the management system, were either rejected outright or greatly watered down. The idea was that, to make the standard acceptable to all sizes and nationalities of organizations, it had to be watered down to a lowest common denominator. Interestingly, the U.S. delegation found it in its interest, given the domestic regulatory context, to champion the cause of the small and less developed nations when the result would be an overall watering down of the standards.

The public process, in contrast, has evolved some mechanisms to deal with the differential capabilities of different actors that avoids the lowest common denominator result. Extended timetables, more stringent obligations for rich countries, technical and financial assistance, and equivalent methods of compliance, are all ideas used in one or more treaties ${ }^{4}$ to allow LDCs to sign on without decreasing the obligations of those who can comply with the full range of obligations. These were conspicuously absent, at least in the environmental management context.

A second major area of difference concerns the treatment of public access to information. One of the hallmarks of public lawmaking on the environment in the last few years has been increasing attention to the need for public access to information on environmental impacts, as a prerequisite to meaningful public participation in environmental decisions. While most treaties and declarations focus on access to information in the hands of public authorities, some have encouraged private entities to make public relevant information. ${ }^{5}$

\footnotetext{
${ }^{4}$ See, e.g., Montreal Protocol on Substances that Deplete the Ozone Layer, reprinted in 26 ILM 1541, 1555 (1987), art. 5; UN Framework Convention on Climate Change, reprinted in 31 ILM 949 (1992); see generally Peter H. Sand, Lessons Learned in Global Environmental Governance (1990).

${ }^{5}$ See, e.g., Agenda 21, Chapter 30.10(a), recommending that companies report annually on their environmental records, including use of energy and national resources; and UN Economic Commission for Europe, Ministerial Conference "Environment for Europe," Draft Guidelines on Access to Environmental Information and Public Participation in Environmental Decision Making, October 23-25, 1995, ECE/CEP/24, I (14), calling on states to encourage entities whose activities have a significant adverse impact on the environment to report regularly to the public on the environmental impact of their activities.
} 